\title{
ANALISIS KEGIATAN USAHATANI BUDIDAYA RUMPUT LAUT (Eucheuma cottonii) DI KOTA TUAL PROVINSI MALUKU
}

\author{
Syahibul Kahfi Hamid*, Haryati La Kamisi** \\ "Staf Polteknik Perikanan Tual, $\boldsymbol{e}$-mail: - \\ ** Staf Pengajar Faperta UMMU-Ternate, e-mail: -
}

\begin{abstract}
ABSTRAK
Penelitian ini bertujuan untuk; 1). Mengetahui tingkat rata-rata pendapatan petani budidaya rumput laut (Eucheuma cottonii) di kota Tual; 2). Mengetahui tingkat efisiensi usahatani budidaya rumput laut (Euchema cottonii) di kota Tual; 3). Mengetahui titik impas (BEP) dari usahatani budidaya rumput laut (Eucheuma cottonii) di kota Tual; 4). Mengetahui berapa lama waktu yang diperlukan untuk menutupi investasi yang ditanamkan pada usahatani budidaya (Eucheuma cottonii) di kota Tual. Metode analisis yang digunakan adalah; 1). Analisis Biaya, Penerimaan, dan Pendapatan Usahatani Rumput Laut; 2). Analisis Tingkat Efisiensi; 3). Nilai break event point (BEP) dan 4). Analisis Payback Period. Hasil penelitian menunjukan bahwa Tingkat efisiensi usaha rumput laut dalam satu musim dengan analisis $R / C$ rasio sebesar 1,20, hal ini berarti usaha tersebut dikatakan efisien dan menguntungkan karena nilai $R / C$ rasio lebih besar dari 1. Analisis titik impas (BEP) usaha rumput laut dalam satu musim di dapat BEP volume produksi sebesar $644 \mathrm{~kg}$, dan BEP harga produksi sebesar Rp. 5.289. Hal ini berarti bahwa selama petani memproduksi diatas $644 \mathrm{~kg}$ dan menjual rumput laut dengan harga diatas $\mathrm{Rp} 5.289$ tiap Kg, maka petani tersebut akan mengalami keuntungan. Hasil perhitungan payback period menunjukan bahwa waktu yang diperlukan untuk pengembalian investasi adalah selama 5 tahun, 1 bulan dan 17 hari.
\end{abstract}

Kata Kunci: Rumput Laut, Pendapatan, Break event point, Payback period

\section{PENDAHULUAN}

\subsection{Latar Belakang}

Pengelolaan sumberdaya pesisir harus memperhatikan tiga hal utama, yaitu: 1) Apapun persepsi pengelolaan sumberdaya pesisir, maka sebagai sumber ekonomi baru yang kompetitif haruslah bermuara pada pengurangan kemiskinan masyarakat, 2) Fokus kegiatan pengelolaan sumberdaya pesisir sebagai sumber ekonomi baru harus berangkat pada pemikiran untuk meningkatkan pembangunan kegiatan ekonomi yang berbasis pada sumber daya lokal yang ada, 3) Sedini mungkin membuat rambu-rambu pengelolaan sumberdaya pesisir dengan melibatkan masyarakat.

Rumput laut merupakan komoditi perikanan budidaya yang bernilai ekonomis dengan peluang pasar yang luas, baik dalam negeri maupun luar negeri. Menurut Suhendar (2006) prospek agribisnis rumput laut ini masih sangat menjanjikan baik bagi petani yang membudidayakan maupun industri pengolah rumput laut.

Rumput laut dapat dibudidayakan dalam jumlah yang besar sehingga menjadi salah satu komoditas yang strategis dalam program kegiatan revitalisasi perikanan yang dicanangkan Kementerian Kelautan dan Perikanan. Menurut data pada Pusdatin KKP (2009), volume produksi perikanan budi daya rumput laut adalah $1,944,800$ ton atau $55.07 \%$. Produksi tersebut menduduki peringkat pertama total produksi perikanan budidaya komoditi ikan, udang dan lainnya. Akan tetapi hal tersebut belum mampu memberikan tingkat kesejahteraan yang layak bagi petani budidaya rumput laut.

Tingkat kesejahteraan yang rendah pada masyarakat petani rumput laut terlihat pada rendahnya pendapatan dan lemahnya "posisi tawar" pada hampir setiap transaksi kehidupan ekonominya serta tingginya risiko harus ditanggung karena sifat ikan basah menyebabkan 
nelayan kecil hanya menerima hasil jual yang rendah bahkan tidak jarang menderita rugi.

Suatu usaha yang dilakukan oleh seorang petani rumput laut haruslah menghasilkan keuntungan yag berkelanjutan. Oleh karena itu, perlu untuk dilakukan analisis usaha. Analisis usaha merupakan suatu cara untuk mengetahui tingkat kelayakan dari suatu jenis usaha. Dimana tujuan analisis usaha adalah untuk mengetahui tingkat keuntungan, pengembalian investasi maupun titik impas suatu usaha. Disamping itu dapat juga untuk antisipasi memperbaiki dan meningkatkan keuntungan suatu usaha. (Oktariza. 2006). Dengan demikian analisis usaha pada kegiatan usahatani rumput laut sangat diperlukan mengingat ketidakpastian usaha yang cukup besar, apalagi usaha budidaya rumput laut yang sangat dipengaruhi oleh kualitas air, hama dan penyakit serta keadaan musim.

Dari uraian tersebut maka merupakan hal yang sangat penting untuk melakukan kajian terhadap analisis tingkat rata-rata pendapatan usahatani, tingkat efisiensi ( $\mathrm{r} / \mathrm{c}$ ratio) dan titik impas (BEP) usaha petani budidaya rumput laut (Eucheuma cottonii) di kota Tual.

\subsection{Perumusan Masalah}

Berdasarkan latar belakang tersebut, maka permasalahan dalam penelitian ini dapat dirumuskan sebagai berikut :

1. Seberapa besar tingkat rata-rata pendapatan petani budidaya rumput laut (Eucheuma cottonii) di kota Tual?

2. Bagaimana tingkat efisiensi usahatani budidaya rumput laut (Euchema cottonii) di kota Tual?

3. Bagaimana titik impas (BEP) dari usahatani budidaya rumput laut (Eucheuma cottonii) di kota Tual?

4. Berapa lama waktu yang diperlukan untuk menutupi investasi yang ditanamkan pada usahatani budidaya (Eucheuma cottonii) di kota Tual?

\subsection{Tujuan Penelitian}

Berdasarkan rumusan masalah, maka penelitian ini bertujuan :

1. Mengetahui tingkat rata-rata pendapatan petani budidaya rumput laut (Eucheuma cottonii) di kota Tual.

2. Mengetahui tingkat efisiensi usahatani budidaya rumput laut (Euchema cottonii) di kota Tual.
3. Mengetahui titik impas (BEP) dari usahatani budidaya rumput laut (Eucheuma cottonii) di kota Tual.

4. Mengetahui berapa lama waktu yang diperlukan untuk menutupi investasi yang ditanamkan pada usahatani budidaya (Eucheuma cottonii) di kota Tual.

\subsection{Kegunaan Penelitian}

Berdasarkan penelitian ini, kegunaan penelitian adalah:

1. Penelitian ini diharapkan memberikan pertimbangan dalam perbaikan sistem usahatani budidaya rumput laut di kota Tual untuk tujuan peningkatan efisiensi usahatani rumput laut.

2. Memberikan kontribusi positif terhadap khasanah perkembangan ilmu pengetahuan bidang analisis usaha perikanan

3. Penelitian ini dapat juga menjadi rujukan bagi para peminat bidang ilmu agribisnis perikanan.

\section{METODE PENELITIAN}

\subsection{Pendekatan Penelitian}

Penelitian dilakukan dengan kombinasi pendekatan kualitatif dan kuantitatif. Pendekatan kualitatif lebih ditekankan pada upaya mendeskripsikan fenomena sosial dan ekonomi petani rumput laut. Demikian juga dengan aktivitas usahatani oleh petani rumput laut. Sedangkan pendekatan kuantitatif dilakukan dengan menggunakan metode analisis data.

\subsection{Tempat dan Waktu Penelitian}

Di kota Tual terdapat empat kecamatan yakni, kecamatan dullah selatan, kecamatan dullah utara, kecamatan tayando tam dan kecamatan pulau-pulau kur. Penelitian ini dilakukan di Kecamatan Dullah Utara, pemilihan lokasi tersebut dilakukan secara purposive dengan dasar bahwa daerah tersebut merupakan sentra produksi utama rumput laut di kota Tual. Waktu penelitian dilakukan selama 3 bulan di mulai bulan Januari - Maret 2011.

\subsection{Metode Pengambilan Sampel}

Unit analisis dalam penelitian ini adalah petani rumput laut. Jumlah sampel petani yang diambil tergantung pada heterogenitas populasi dan tingkat representativitas yang dikehendaki. Di kota Tual terdapat 40 desa yang tersebar di empat kecamatan, sedangkan di Kecamatan Dullah Utara terdapat 11 desa, dimana terdapat 3 desa sebagai penghasil rumput laut terbesar di 
kecamatan tersebut. Dari ketiga desa tersebut diperkirakan terdapat sekitar 100 orang petani rumput laut. Jumlah ini diambil semua secara sensus sebagai sampel penelitian. Resiko bias dalam pengambilan sampel diharapkan dapat diminimisasi dan kesimpulan yang ditarik dapat mewakili populasi yang diteliti (Nasution, 2003).

\subsection{Metode Pengumpulan Data}

Data yang diperlukan dalam penelitian ini dapat dikelompokkan atas dua kategori yaitu : data sekunder dan data primer. Untuk merrperoleh kedua data tersebut secara akurat maka dilakukan teknik pengambilan data sebagai berikut

1. Observasi. Merupakan suatu teknik pengambilan data dengan mengamati secara langsung objek penelitian dan mencatat secara sistematis gejala-gejala yang terkait.

2. Studi kepustakaan (library research). Merupakan teknik pengambilan data dengan menelaah suatu kepustakaan / reference serta laporan-laporan instansi yang terkait.

3. Wawancara. Merupakan teknik pengambilan data dengan mengajukan pertanyaan secara langsung terhadap responden dengan berpedoman kepada kuisioner.

\subsection{Analisis Data Kegiatan Usahatani Rumput Laut.}

2.5.1. Analisis Biaya, Penerimaan, dan Pendapatan Usahatani Rumput Laut.

Komponen biaya total terdiri dari biaya variabel (biaya tidak tetap) dan biaya tetap. Biaya variabel adalah biaya yang secara total berubah secara proporsional dengan perubahan aktivitas, dengan kata lain biaya variabel adalah biaya yang besarnya dipengaruhi oleh jumlah produksi yang dihasilkan, akan tetapi biaya variabel per unit sifatnya konstan. Sedangkan biaya yang selalu tetap secara keseluruhan tanpa terpengaruh oleh tingkat aktivitas (Garrison dan Noreen 2001).

Analisis ini dilakukan dengan melakukan perhitungan :

a. Total Biaya $\mathrm{TC}=\mathrm{VC}+\mathrm{FC}$

Dimana $: \mathrm{TC}=$ total cost $/$ total biaya

$$
\mathrm{VC}=\text { variabel cost } / \text { biaya variabel }
$$$$
\mathrm{FC}=\text { fixed cost } / \text { biaya tetap }
$$

b. Total penerimaan TR $=\mathrm{P} . \mathrm{Q}$

Dimana $: T R=$ total revenue $/$ total penerimaan

$$
\mathrm{P}=\text { harga jual per unit }(\mathrm{kg})
$$$$
\mathrm{Q}=\text { jumlah produk yang dijual }(\mathrm{kg})
$$

c. Total Pendapatan $\pi=\mathrm{TR}-\mathrm{TC}$

Jika pendapatan petani rumput laut <

Upah Minimum Regional (UMR) yang dikeluarkan oleh Pemerintah Provinsi Maluku tahun 2011 yakni sebesar Rp. 900.000. maka pendapatan petani dikategorikan rendah.

Dimana :

$\pi=$ Pendapatan petani (profit $/$ keuntungan)

\subsubsection{Tingkat Efisiensi Usahatani Rumput Laut}

Untuk mengukur tingkat efisiensi usaha digunakan analisis Return Cost Ratio (R/C Ratio) yaitu perbandingan atau nisbah antara penerimaan dan biaya. Secara matematis dapat ditulis sebagai berikut:

$$
\mathrm{R} / \mathrm{C} \text { Ratio }=\frac{T R}{T C}
$$

Dengan kriteria pengujian sebagai berikut:

- Jika R/C Ratio > 1, maka usaha rumput laut efisien dan menguntungkan.

- Jika R/C Ratio = 1, maka usaha rumput laut tidak menguntungkan dan tidak rugi (impas).

- Jika R/C Ratio < 1, maka usaha rumput laut tidak efisien dan tidak menguntungkan.

2. Nilai break event point (BEP) Usahatani Rumput Laut

Merupakan sebuah pengukuran untuk mengetahui berapa volume / Kapasitas produksi minimum dan berapa harga yang harus dikeluarkan agar investasi itu tidak menderita rugi tetapi juga belum memperoleh keuntungan / laba. BEP dapat dihitung dengan mengetahui biaya tetap, biaya produksi dan hasil penjualan (Indriani dan Suminarsih 2003).

$$
\begin{aligned}
& \mathrm{TR}=\mathrm{TC} \\
& \mathrm{P} \cdot \mathrm{Q}=\mathrm{VC}+\mathrm{FC}
\end{aligned}
$$

\section{- Break Even Point Volume Produksi}

$$
\text { BEP Produksi }=\frac{\text { Total Biaya Produksi }(\mathrm{Rp})}{\text { Total Harga Penjualan }(\mathrm{Rp} / \mathrm{Kg})}
$$

- Break Even Point Harga Produksi

BEP Harga $=$

Total Biaya Produksi (Rp)

Jumlah Total Produksi (Kg)

\subsubsection{Payback Period}

Penghitungan PBP untuk mengetahui jumlah periode (tahun) yang diperlukan untuk mengembalikan (menutup) ongkos investasi awal dengan tingkat pengembalian tertentu (Giyatmi et al. 2003). Metode payback period merupakan 
metode menghitung seberapa cepat investasi yang dilakukan bisa kembali (Husnan 1996). Rumus yang digunakan adalah :

\section{Investasi}

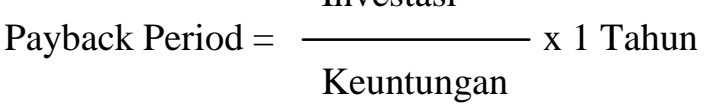

\section{HASIL DAN PEMBAHASAN}

\subsection{Kegiatan Usahatani Budidaya Rumput Laut (Eucheuma cottonii)}

Rumput laut tergolong tanaman berderajat rendah, umumnya tumbuh melekat pada substrat tertentu, tidak mempunyai akar, batang maupun daun sejati. Tapi hanya mempunyai batang yang disebut thallus. Rumput laut tumbuh di alam dengan melekatkan dirinya pada karang, lumpur, pasir, batu dan benda keras lainnya. Rumput laut yang di budidayakan di Kota Tual adalah rumput laut jenis Eucheuma cottonii, dimana rumput laut jenis ini memerlukan sinar matahari untuk proses fotosintesis, sehingga rumput laut ini hanya akan hidup pada kedalaman sejauh sinar matahari masih mampu mencapainya.

Hasil pengamatan dan wawancara yang dilakukan pada petani rumput laut di Kota Tual lebih khusus pada Kecamatan Dullah Utara dimana data yang diambil di Desa Dullah Laut sebanyak 50 responden, di Desa Watran 30 responden dan di Desa Fiditan sebanyak 20 responden, dengan total responden sebanyak 100 orang. Dimana ketiga desa tersebut merupakan desa sentral produksi rumput laut di Kota Tual. Lama usahatani rumput laut dari penanaman bibit, pemeliharaan, panen hingga penjualan selama 60 - 65 hari, dengan rata-rata 4 - 5 siklus panen dalam satu tahun.

Metode budi daya rumput laut yang dikenal secara umum adalah : 1) metode lepas dasar yang dilakukan di atas dasar perairan yang berpasir atau pasir berlumpur dan terlindung dari hempasan gelombang besar; 2) metode rakit apung yang dilakukan dengan cara mengikat rumput laut pada tali dan diikatkan pada rakit apung yang terbuat dari bambu; 3) metode rawai dan dikenal dengan istilah longline yang menggunakan tali panjang yang dibentangkan; dan 4) metode jalur yang merupakan kombinasi antara metode rakit apung dengan rawai (Sudradjat 2008).

Kegiatan budidaya rumput laut di Kecamatan Dullah Utara. Dilakukan dengan metode rawai, karena disamping fleksibel dalam memilih lokasi budidaya juga biaya yang dikeluarkan relatif lebih terjangkau oleh petani budidaya rumput laut. Hal ini sesuai dengan pendapat Anggadiredja et al. (2006), bahwa metode rawai merupakan cara yang paling banyak diminati petani rumput laut karena disamping fleksibel dalam pemilihan lokasi, juga biaya yang dikeluarkan relatif murah. Keuntungan dari metode ini adalah tanaman terbebas dari hama bulu babi, pertumbuhannya lebih cepat dan lebih murah ongkos materialnya. Metode ini dimasyarakatkan karena selain lebih ekonomis juga dapat diterapkan di perairan yang agak dalam.

Umumnya bibit rumput laut akan diikat pada tali dengan jarak sekitar 20-25 cm, dengan panjang tali mencapai 30-50 m. Untuk mengapungkan rumput laut biasanya petani setempat menggunakan botol bekas minuman air mineral $500 \mathrm{ml}$, disamping menggunakan pelampung utama dikedua ujung tali. Supaya rumput laut tidak mengapung di permukaan dan tetap berada pada kedalaman $6-12 \mathrm{~cm}$ dibawah permukaan laut pelampung-pelampung tersebut diikatkan ke tali dengan jarak 10-15 cm.

Sedangkan untuk menjaga agar rumput laut tidak hanyut, maka petani mengikatkan kedua ujung tali utama dengan pemberat, pemberat yang digunakan umumnya jangkar, batu atau batu karang. Untuk lebih jelasnya tentang teknik budidaya rumput laut dengan metode rawai dapat dilihat pada Gambar 1 .

Pemeliharaan dilakukan hingga panen berkisar antara 45-50 hari, kegiatan pemeliharaan meliputi: pembersihan tali dan tanaman dari kotoran, tumbuhan dan hewan pengganggu. Menyulam/menyisip tanaman yang mati atau terlepas dari ikatan setelah rumput laut ditanam. Mengganti tali, patok, pelampung yang lapuk/rusak, menguatkan tali ikatan dan tali jangkar yang sudah goyah. Membersihkan lumpur yang melekat pada tanaman dan tali, serta pemantauan pertumbuhan rumput laut secara berkala. Kerusakan patok, jangkar, tali ris, tali ris utama dan pelampung disebabkan oleh ombak besar atau daya tahan rumput laut menurun sehingga harus segera diperbaiki. Bila ditunda berakibat makin banyak yang hilang sehingga kerugian semakin besar. Disamping itu juga dilakukan perlindungan terhadap predator seperti ikan dan penyu.

Mutu rumput laut tidak hanya dipengaruhi oleh teknik atau metode budidayanya saja, pemanenan juga merupakan hal terpenting dalam menentukan mutu rumput laut seperti penentuan umur panen, cara panen dan keadaan cuaca pada saat pemanenan. Pemanenan yang 
dilakukan petani dengan cara melepas rumput laut dari ikatan dan selanjutnya diletakan didalam perahu yang telah disiapkan. Setelah dibawa ke darat rumput laut ditimbang dan selanjutnya dijemur selama 3-4 hari. Rumput laut dijemur diatas rak bambu atau dengan menggunakan tarpal. Umumnya petani dibantu oleh tenaga kerja sebanyak 1-3 org. tergantung dari luas bentangan usaha budidaya rumput laut.

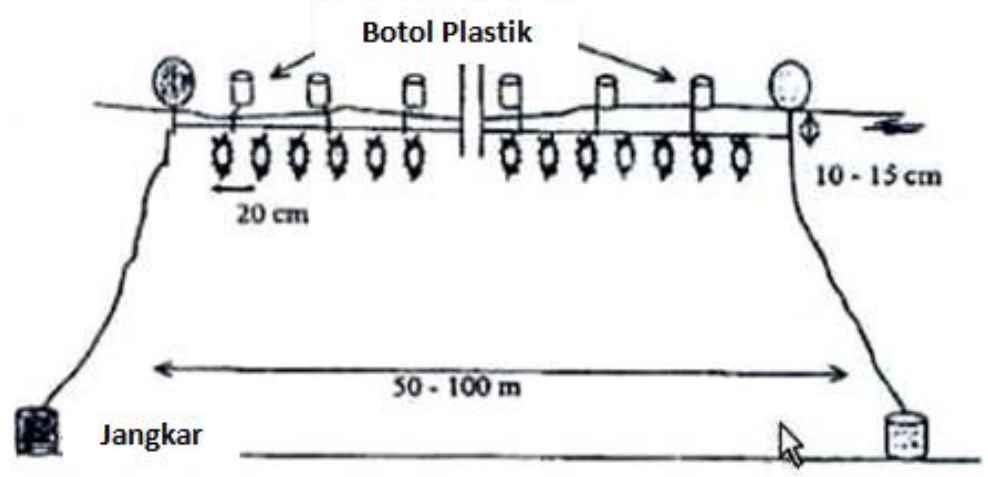

Gambar 1. Metode Rawai Dalam Usahatani Rumput Laut.

Penanganan rumput laut pada pasca panen memegang peranan yang sangat penting dalam kegiatan usaha rumput laut. Kegiatan pasca panen sangat menentukan mutu rumput laut kering yang dihasilkan sebagai bahan baku industri selanjutnya. Kegiatan penanganan ini harus dilakukan secara seksama baik dari pemanenan, pencucian, pengeringan bahkan sampai pengepakan dan penyimpanannya. Perlakuan sebelum pengeringan dilakukan sesuai permintaan pasar, yaitu: langsung dijemur sesudah panen, terlebih dulu dicuci dengan air tawar terlebih dahulu. Penanganan hasil panen ini juga harus disesuaikan dengan kegiatan pengolahan selanjutnya. Kegiatan pengolahan ditujukan untuk menciptakan suatu produk yang lebih bernilai ekonomis daripada bahan mentahnya. Dalam arti, produk olahan apa yang akan dihasilkan dari jenis rumput laut yang dipanen. Hal ini tentu saja agar mutu rumput laut yang dihasilkan sebagai bahan baku sesuai dengan standar produksi industri pengolahannya dan menghasilkan produk olahan yang berkualitas baik.

\subsection{Analisis Biaya, Penerimaan, dan} Pendapatan Usahatani Budidaya Rumput Laut (Eucheuma cottonii) di Kota Tual.

Keragaan analisis usahatani rumput laut di kecamatan dullah utara kota Tual, disajikan selengkapnya pada lampiran 1 . Dimana dari data yang diperoleh total produksi dari 100 responden sebesar $322.183 \mathrm{~kg}$ total rumput laut basah dengan rata-rata per petani sebesar $3.222 \mathrm{~kg}$ atau $77.516 \mathrm{~kg}$ total rumput laut kering dengan rata- rata per petani $775 \mathrm{~kg}$. Dengan rata-rata pengeluaran dari total 100 responden petani didapat sebesar Rp. 4.000.092, untuk penerimaan yakni sebesar Rp. 4.910.024, dan rata-rata keuntungan yang diperoleh sebesar Rp. 809.932. Jika dibandingkan dengan upah minimum regional (UMR) yang dikeluarkan oleh Pemerintah Provinsi Maluku tahun 2011 yakni sebesar Rp. 900.000, maka pendapatan petani tersebut masih dikategorikan rendah. Untuk analisis tingkat pendapatan usahatani rumput laut dapat dilihat pada Tabel 1.

Tabel 1. Analisis Tingkat Rata-rata Pendapatan Usahatani Rumput Laut (Eucheuma cottonii) di Kecamatan Dullah Utara Kota Tual.

\begin{tabular}{|c|c|c|}
\hline \multicolumn{2}{|c|}{ Uraian } & (Rp) \\
\hline \multirow{4}{*}{$\begin{array}{c}\text { Tingkat } \\
\text { Rata-rata } \\
\text { Pendapat } \\
\text { an Petani }\end{array}$} & Total & 491.002 .388 \\
\hline & Penerimaan & \\
\hline & $\begin{array}{c}\text { Total Biaya } \\
\text { Usaha }\end{array}$ & 410.009 .200 \\
\hline & $\begin{array}{l}\text { Rata-rata } \\
\text { Pendapatan }\end{array}$ & 80.993 .188 \\
\hline
\end{tabular}

Dari hasil pada Tabel tersebut dapat dilihat tingkat pendapatan rata-rata dari usahatani rumput laut, dari hasil analisis yang dilakukan didapat Rp. 80.993.188.

\subsection{Analisis Tingkat Efisiensi Usahatani Budidaya Rumput Laut (Eucheuma cottonii) di Kota Tual. \\ Análisis tingkat efisiensi merupakan} hasil antara penerimaan dan biaya yang dikeluarkan, análisis ini menunjukan sejauh mana pengaruh perubahan biaya terhadap penerimaan 
usaha. Dimana nilai $\mathrm{R} / \mathrm{C}$ ratio pada usahatani ini adalah sebesar 1, 20 hal ini berarti setiap petani yang melakukan usaha budidaya rumput laut dengan mengeluarkan biaya sebesar satu rupiah maka akan memperoleh penerimaan sebesar 1, 20 rupiah. Untuk análisis tingkat efisiensi usahatani rumput laut dapat dilihat pada Tabel 2.

Tabel 2. Analisis Tingkat Efisiensi (R/C ratio) Usahatani Rumput Laut (Eucheuma cottonii) di Kecamatan Dullah Utara Kota Tual.

\begin{tabular}{clr} 
& Uraian & \multicolumn{1}{c}{ (Rp) } \\
\hline Tingkat & Total Penerimaan & 491.002 .388 \\
Efisiensi & Total Biaya Usaha & 410.009 .200 \\
\cline { 2 - 3 } Usaha & R/C Ratio & $\mathbf{1 . 2 0}$ \\
\hline
\end{tabular}

Tingkat efisiensi usaha rumput laut dalam satu musim dengan analisis $\mathrm{R} / \mathrm{C}$ rasio sebesar 1,20, hal ini berarti usaha tersebut dikatakan efisien dan menguntungkan karena nilai $\mathrm{R} / \mathrm{C}$ rasio lebih besar dari 1 .

\subsection{Analisis Titik Impas (BEP) Usahatani Budidaya Rumput Laut (Eucheuma cottonii) di Kota Tual. \\ Break Event Point adalah suatu kondisi} dimana modal telah kembali semua atau pengeluaran sama dengan penerimaan, pada saat BEP dicapai usaha tidak untuk maupun rugi. BEP dapat dihitung dengan mengetahui biaya tetap, biaya produksi dan hasil penjualan, análisis BEP ini dimaksud untuk mengetahui berapa unit mínimum yang harus dihasilkan agar usahatani rumput laut tidak mengalami kerugian. Análisis BEP usahatani rumput laut dapat dilihat pada Tabel 3.

Tabel 3. Analisis Titik Impas (BEP) Usahatani Rumput Laut (Eucheuma cottonii) di Kecamatan Dullah Utara Kota Tual.

\begin{tabular}{clr}
\hline \multicolumn{2}{c}{ Uraian } & \multicolumn{1}{c}{ (Rp) } \\
\hline \multirow{3}{*}{ Titik Impas (BEP) } & Total Biaya Usaha & 410.009 .200 \\
Volume Produksi & Potal Harga & 636.250 \\
\cline { 2 - 3 } & Penjualan & \\
& PEP Volume & 644 \\
\hline & Produksi (Kg) & \\
Titik Impas (BEP) & Total Biaya Usaha & 410.009 .200 \\
Harga Produksi & (Kg) & 77.516 \\
\cline { 2 - 3 } & BEP Harga & \\
& Produksi (Rp/Kg) & 5.289 \\
\hline
\end{tabular}

Analisis titik impas (BEP) usaha rumput laut dalam satu musim di dapat BEP volume produksi sebesar $644 \mathrm{~kg}$, dan BEP harga produksi sebesar Rp. 5.289. Hal ini berarti bahwa selama petani memproduksi diatas $644 \mathrm{~kg}$ dan menjual rumput laut dengan harga diatas $\mathrm{Rp} 5.289$ tiap $\mathrm{Kg}$, maka petani tersebut akan mengalami keuntungan.

\subsection{Analisis Payback Period Usahatani Budidaya Rumput Laut (Eucheuma cottonii) di Kota Tual.}

Payback period adalah suatu periode yang diperlukan untuk menutup kembali pengeluaran investasi yang dikeluarkan oleh petani dalam usaha budidaya rumput laut. Análisis ini bertujuan untuk mengetahui waktu yang diperlukan dalam tahun atau bulan. Hal ini dalam dilihat pada Tabel 4.

Tabel 4. Analisis Payback Period Usahatani Rumput Laut (Eucheuma cottonii) di Kecamatan Dullah Utara Kota Tual.

\begin{tabular}{clr}
\hline & Uraian & \multicolumn{1}{c}{ (Rp) } \\
\hline \multirow{3}{*}{$\begin{array}{c}\text { Payback } \\
\text { Period }\end{array}$} & Total Biaya Usaha & 410.009 .200 \\
\cline { 2 - 3 } & Rata-rata Pendapatan & 80.993 .188 \\
\cline { 2 - 3 } & Payback Period & 5,1 \\
& (Tahun) & \\
\hline
\end{tabular}

Hasil perhitungan payback period menunjukan bahwa waktu yang diperlukan untuk pengembalian investasi adalah selama 5 tahun, 1 bulan dan 17 hari.

Dari hasil analisis usahatani tersebut menunjukan bahwa, usahatani di Kecamatan Dullah Laut yang dilakukan oleh petani cukup memberikan keuntungan, akan tetapi dilihat dari lama menunggu penghasilan yang kurang lebih sekitar 2 bulan dinilai masih kurang jika dibandingkan dengan kebutuhan hidup petani sehari-hari dengan pendapatan Rp. 405.000 per bulan.

Hal ini disebabkan karena usahatani rumput laut di kota Tual masih didominasi oleh pedagang pengumpul dalam hal ini selaku pembeli, dan petani senantiasa memiliki posisi tawar yang rendah dalam penentuan harga jual rumput laut, karena adanya ikatan yang kuat antara petani rumput laut dan pedagang pengumpul dalam peminjaman modal usaha serta peminjaman biaya hidup sehari-hari, sehingga memposisikan petani senantiasa sebagai pihak yang lemah dalam penentuan harga jual rumput laut. Dengan demikian perlu adanya solusi dari pemerintah maupun pihak yang terkait dalam hal ini tentang kredit usaha rakyat kepada petani rumput laut. Sehingga petani rumput laut dapat melakukan usaha secara mandiri tanpa di pengaruhi oleh pedagang pengumpul. 
Kesulitan modal berupa uang menjadikan para petani rumput laut sangat tergantung kepada pedagang pengumpul karena mereka meminjam uang kepada pedagang pengumpul sehingga sebagian hasil panen dibayar untuk menutup hutang modal usaha. Petani rumput laut belum dapat sepenuhnya terbebas dari hutang para lintah darat dan pedagang pengumpul padahal sektor perbankan sudah dilibatkan dalam pemanfaatan potensi rumput laut dalam hal ini melalui program kredit usaha rakyat (KUR). Fasilitas perbankan sudah ada namun petani belum memanfaatkan karena kurangnya informasi untuk dapat mengakses program tersebut.

\section{KESIMPULAN DAN SARAN \\ 4.1. Kesimpulan}

Berdasarkan penelitian yang dilakukan, dapat disimpulkan sebagai berikut :

1. Total produksi rumput laut basah sebesar $322.183 \mathrm{~kg}$ dengan rata-rata per petani sebesar $3.222 \mathrm{~kg}$ atau $77.516 \mathrm{~kg}$ total rumput laut kering dengan rata-rata per petani $775 \mathrm{~kg}$. Dengan rata-rata pengeluaran dari petani didapat sebesar Rp. 4.000.092, untuk penerimaan yakni sebesar Rp. 4.910.024, dan rata-rata keuntungan yang diperoleh sebesar Rp. 809.932. Jika dibandingkan dengan upah minimum regional (UMR) yang dikeluarkan oleh Pemerintah Provinsi Maluku tahun 2011 yakni sebesar Rp. 900.000, maka pendapatan petani tersebut masih dikategorikan rendah.

2. Tingkat efisiensi usaha rumput laut dalam satu musim dengan analisis $\mathrm{R} / \mathrm{C}$ rasio sebesar 1,20 , hal ini berarti usaha tersebut dikatakan efisien dan menguntungkan karena nilai $\mathrm{R} / \mathrm{C}$ rasio lebih besar dari 1 .

3. Analisis titik impas (BEP) usaha rumput laut dalam satu musim di dapat BEP volume produksi sebesar $644 \mathrm{~kg}$, dan BEP harga produksi sebesar Rp. 5.289. Hal ini berarti bahwa selama petani memproduksi diatas 644 $\mathrm{kg}$ dan menjual rumput laut dengan harga diatas Rp 5.289 tiap $\mathrm{Kg}$, maka petani tersebut akan mengalami keuntungan.

4. Hasil perhitungan payback period menunjukan bahwa waktu yang diperlukan untuk pengembalian investasi adalah selama 5 tahun, 1 bulan dan 17 hari.

\subsection{Saran}

Untuk memperbaiki usaha budidaya rumput laut (Eucheuma cottonii) agar lebih menguntungkan lagi bagi petani, maka :

1. Petani rumput laut memerlukan suatu organisasi sebagai pusat informasi dan penyelesaian permasalahan-permasalahan yang sering di alami baik dari segi produksi maupun kegiatan pasca panen.

2. Usaha rumput laut di kota Tual masih sangat didominasi oleh pedagang terutama dalam hal penentuan harga jual rumput laut, karena adanya ikatan yang kuat antara petani rumput laut dan pedagang setempat dalam hal peminjaman modal usaha serta peminjaman biaya hidup sehari-hari, sehingga perlu sosialisasi tentang adanya kredit usaha rakyat (KUR) oleh pemerintah. Sehingga petani rumput laut dapat melakukan usaha secara mandiri tanpa di pengaruhi oleh pedagang.

\section{DAFTAR PUSTAKA}

Anggadiredja JT, A Zatnika, H Purwoto, S. Istini. 2006. Rumput Laut: Pembudidayaan, Pengolahan dan Pemasaran Komoditas Perikanan Potensial. Penebar Swadaya. Jakarta. 147hal

Husnan S. 1996. Manajemen Keuangan (Keputusan Jangka Panjang), Edisi Keempat. Yogyakarta: BPFE

Indriani H dan E Sumarsih. 2003. Agribisnis Rumput Laut. Bogor. Penebar Swadaya.

Garrison RH dan EW Noreen. 2001. Akutansi Manajerial. Salemba Empat. Jakarta

Giyatmi, AH Purnomo, M Hubeis. 2003. Analisis Produk Unggulan Agroindustri Perikanan Laut di Kabupaten Rembang. Jurnal Penelitian Perikanan Indonesia; 9 (6): 75 - 87

Nasution, S. 2003. Metode Research (Penelitian Ilmiah). Edisi Pertama. Bumi Aksara. Jakarta.

Oktariza W dan Irzal Effendi. 2006. Manajemen Agribisnis Perikanan. Penebar Swadaya. Jakarta. 163hal.

(Pusdatin KKP) Pusat Data, Statistik dan Informasi, Kementerian Kelautan dan Perikanan. 2009. Indikator Kelautan dan Perikanan Agustus 2009. Jakarta

Sudradjat A. 2008. Budidaya 23 Komoditas Laut Menguntungkan. Penebar Swadaya. 171p. Jakarta.

Suhendar, S. 2006. Pengembangan Agribisnis Komoditi Rumput Laut Melalui Model Klaster Bisnis. Infokop Nomor 28 Tahun XXII, 2006 Hal 71 - 78. 